\title{
Inventory Control Effect on Profitability of a Business Organization
}

\author{
Orumie, Ukamaka Cynthia \\ Department of Mathematics/Statistics, University of Port Harcourt, Nigeria
}

\begin{abstract}
A survey on the effect of inventory control on profitability of a business organization was carried out on DUFIL Prima Foods Limited at Choba, Port Harcourt. Questionnaires were used to obtain the views of the workers on whether the profitability of a business organizationdepends on inventory control or not. In order to get the frequency and percentage of the responses, descriptive statistics were used, whereas the Chi-square test was used to test the hypothesis using Statistical Package for Social Sciences (SPSS) version 16. The graph showed that the age of staff within the range of 26-35 years recorded the highest number of respondents with majority of men who are married. Also they are mostlyB.SC/HND holders with at least five years of experience.The Chi square results showed that inventory control affects the profit position of the company significantly. Also, result revealed dicates that inventory control determines when goods that have been exhausted from the store so that replacement can be made and that inventory control system of any organization will eventually affect the success of that organization.
\end{abstract}

Keywords: Survey, Business organization, Chi-square, Test of hypothesis

\section{Introduction}

Inventory is a physical stock of goods that a business organization have at hand forsmooth running of itsbusiness. It is the quantity of available goods, raw materials or other resource (items)that are idle at any given time. They include company's raw materials; work in progress, supplies used in operations and finished goods, and these could be outdated, neglected, or imperfect shapes, sizes or even an imbalancein several product chains that affects customersrequest of the total activities.

Obviously, absence of control measures while carrying out actionis wasting of time and resources. Irrespectiveof the economic melt down in Nigeria, where companies are shut down due to hike in prizes of importation, devaluation of the currency, high exchange rate, and many more, a good number of manufacturing companies that are presently in operation keep floating and maintain their standards. This is because of management such as inventory control which is crucial to all sectors of the economy since it requires the ability of the managerial team to consider when to increase or maintain stock levels in order not to miss her target.

The importance of inventory control system has been addressed by many authors like; Sunil \& Sameer(1998) who was able to summarise the issues surrounding inventory systems control.

Inventory models determines the Economic Order Quantity (EOQ) which optimizes the total cost inventory for that item, where as EOQ is a calculated re-order quantity which minimizes the balance of cost between carrying costs and ordering costs. This implies that there are some factors to take into consideration in the formulation of EOQ inventory model

And they are: how much to order, when to order, when item of stock is to be replenished and when to order.

Also, Osborne, and Plastrik, (1997) addressed the issues about utility of manufacturing inventory systems. He pinpointed that a major management issue is determining the inventory control system's performance. They were of the opinion that manufacturing industry performance is determined by inventory carrying costs and turnover.

Silver (1981), Okoth (2012) and many others have also addressed inventroy problems in a manufacturing company in different ways.

However the researcher wants to find out if inventory control will influence the profitability of a business organization, and to determine the extent at which it will be affected, and however determine the general effect of inventory control on a business organization using DUFIL Prima Foods Limited at Choba, Port Harcourt as a case study.

In section two, brief history of the company is described. Method of of data collection is summarized in section three with SPSS result output obtained from data collected given in section four. Finally, section five summarizes the main conclusion.

\section{Brief History of Indomie Company (DUFIL Prima Foods Limited Choba, Port Harcourt)}

Indomie is a brand of noodle originated from Indonesiain 1971 by Sudono Salim; a Chinese Indonesian tycoon that also owned Bogasari flour mills. It is the largest instant noodle manufacturer in Indonesia with $72 \%$ of market share. It is distributed in Australia, Asia, Africa, New Zealand, the United States and European and Middle Eastern countries. (euromonitor.com. of March 2014)

In1995, its first production factory in Nigeria was established under Dufil Prima Foods and it is the first instant noodles manufacturing plant in Nigeria and the largest in Africa.

However,De United Foods Industries Limited, Noodle Division, came into existence in 1996 at Ogun State with

Volume 6 Issue 1, January 2017 


\section{International Journal of Science and Research (IJSR) \\ ISSN (Online): 2319-7064 \\ Index Copernicus Value (2015): 78.96 | Impact Factor (2015): 6.391}

about five hundred staff. Currently it has over noe thousand five hundred staff.

DUFIL PRIMA FOODS PLC started its operation in 2001 as a private limited liability company at Choba, Port Harcourt, Rivers State. In 2008, The company was changed Public limited company and became the holding company of the group. Pure Flour Mills Limited, Flour Division, and Pasta Division, commenced at Choba In 2012, Port Harcourt, Rivers State.

\section{Data Collection and Analysis}

The data collection is limited to thestaff of DUFIL Prima Foods Limited Choba, Port Harcourt. Data that were collected and analyzed for this research study were from primary source gathered from the questionnaires and information from personal interview conducted on workers of this company. The questionnaires are the only instrument that was used for evaluating and gathering of data. It was categorized into two parts; the first part covers the biographical data of the respondents, which includesbut not limited to sex, age, marital status, and educational background of staff, whereas the other session are questions relating to the subject matter of the research.

Questionnaires were distributed to one hundred and twenty (120) staff, but only eighty (80) respondents returned theirs, out of which thirty (30) were invalid. Thus fifty (50) respondents formed the sample for this studywhile the population for the research is the entire staff of DUFIL Prima Foods Limited Choba, Port.

The results obtained from various analyses are presented in the various tables below as applied to the research questions.

\section{Data analysis and output results}

The data collected were analyzed using Statistical Package for Social Sciences (SPSS) version 16. In order to get the frequency and percentage of the responses, descriptive statistics were done while Chi square was used to test the hypotheses.

Table 4.1: Sex of respondents

\begin{tabular}{|c|c|c|}
\hline Variables & No of Respondents & \% of Respondents \\
\hline Male & 29 & 55 \\
\hline Female & 21 & 45 \\
\hline Total & 50 & 100 \\
\hline
\end{tabular}

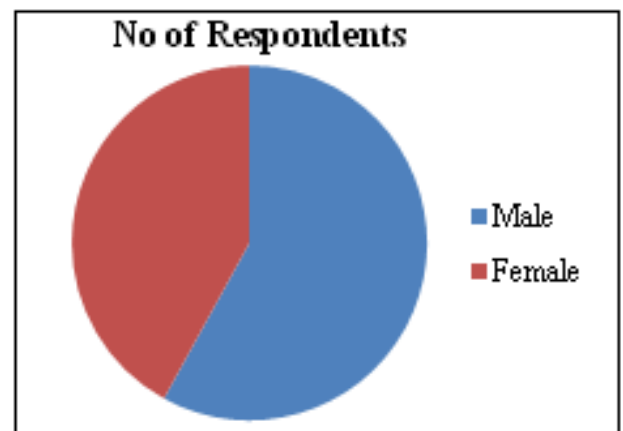

Figure 1: pie chart representation of the sex of respondents
Table 4.2: Marital status of respondents

\begin{tabular}{|c|c|c|}
\hline Variables & $\begin{array}{c}\text { No of } \\
\text { Respondents }\end{array}$ & \% of Respondents \\
\hline Single & 22 & 43 \\
\hline Married & 28 & 57 \\
\hline Total & $\mathbf{5 0}$ & $\mathbf{1 0 0}$ \\
\hline
\end{tabular}

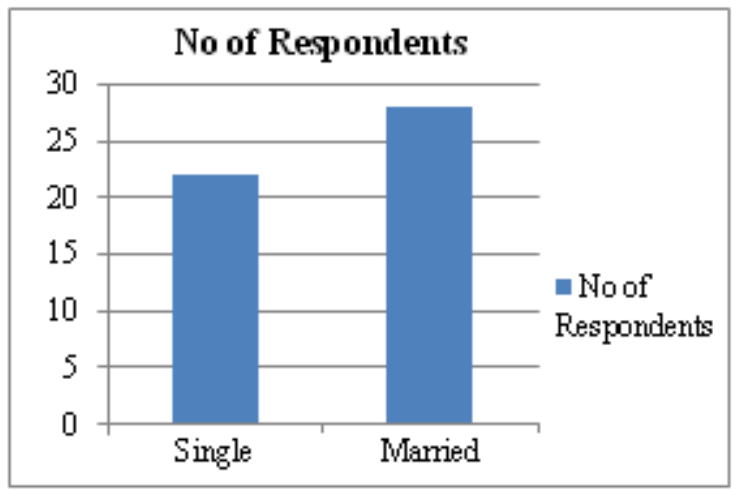

Figure 2: Bar chat representation of the marital status of respondents

Table 4.3: Age distribution of respondents

\begin{tabular}{|c|c|}
\hline Interval & Frequency \\
\hline $16-25$ & 15 \\
\hline $26-35$ & 20 \\
\hline $36-45$ & 10 \\
\hline 45 and above & 5 \\
\hline
\end{tabular}

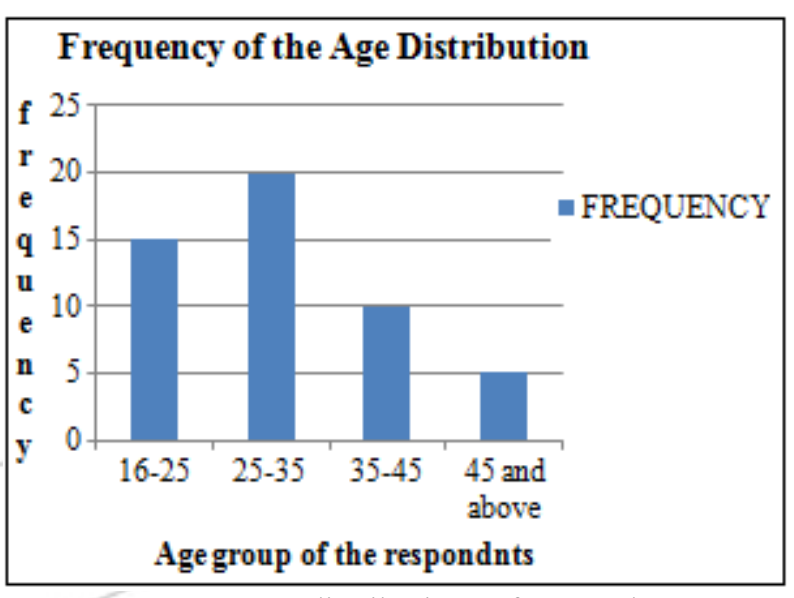

Figure 3: Age distributions of respondents

Table 4.4: Distribution of respondents based on status in the

\begin{tabular}{|c|c|c|}
\hline \multicolumn{3}{|c|}{ company } \\
\hline Variables & $\begin{array}{c}\text { No of } \\
\text { Respondents }\end{array}$ & $\begin{array}{c}\% \text { of } \\
\text { Respondents }\end{array}$ \\
\hline Management & 16 & 32 \\
\hline Supervisory & 14 & 28 \\
\hline Clerical & 11 & 22 \\
\hline Others & 9 & 18 \\
\hline Total & $\mathbf{5 0}$ & $\mathbf{1 0 0}$ \\
\hline
\end{tabular}


International Journal of Science and Research (IJSR)

ISSN (Online): 2319-7064

Index Copernicus Value (2015): 78.96 | Impact Factor (2015): 6.391

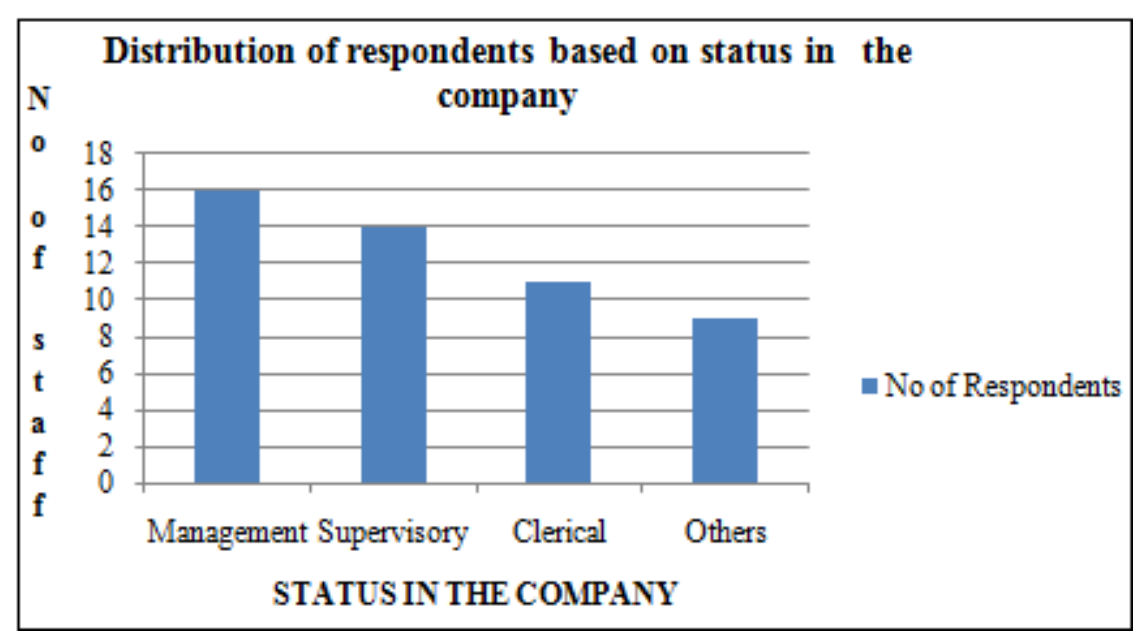

Figure 4: Distribution of respondents based on status in the company

Table 4.5: Distribution of respondents based on educational qualification in the company

\begin{tabular}{|l|l|}
\hline \multicolumn{1}{|c|}{ Educational qualification } & No of Respondents \\
\hline Ordinary Level & 8 \\
\hline OND/NCE & 16 \\
\hline BSC/HND/MSCl & 26 \\
\hline
\end{tabular}

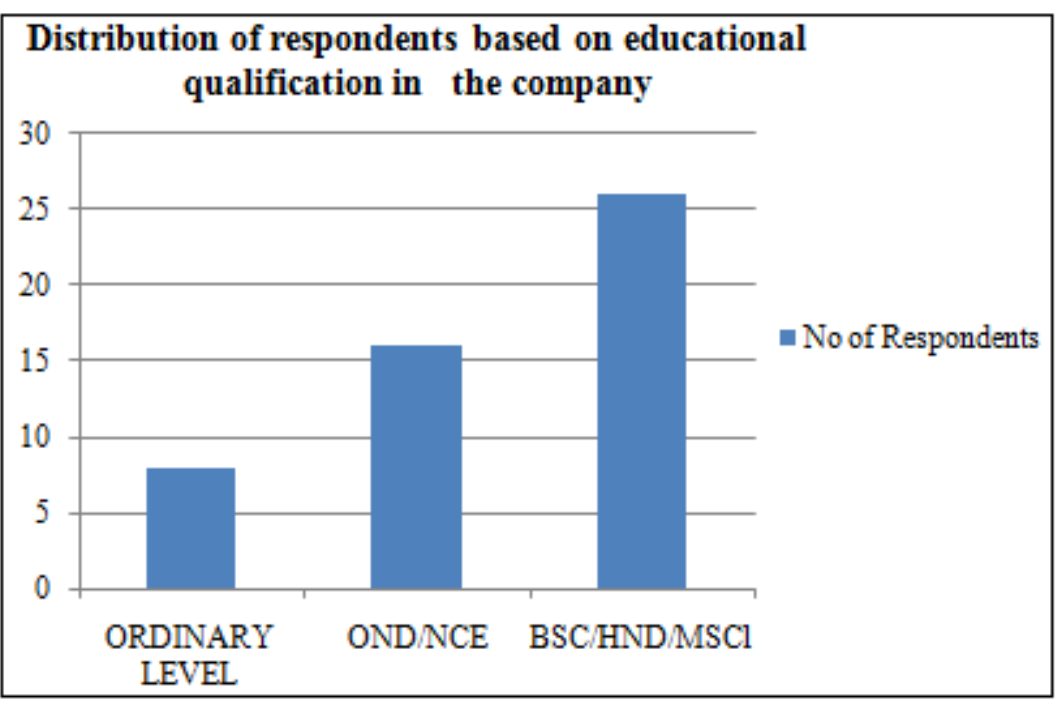

Figure 5: Distribution of respondents by education qualification

Table 4.6: Inventory control management enhance organization profitability

\begin{tabular}{|c|c|c|}
\hline Variables & No of Respondents & \% of Respondents \\
\hline Strongly Agree & 20 & 40 \\
\hline Agree & 15 & 30 \\
\hline Undecided & 11 & 22 \\
\hline Disagree & 4 & 8 \\
\hline Strongly Disagree & - & - \\
\hline Total & 50 & 100 \\
\hline
\end{tabular}

Volume 6 Issue 1, January 2017 www.ijsr.net 
International Journal of Science and Research (IJSR)

ISSN (Online): 2319-7064

Index Copernicus Value (2015): 78.96 | Impact Factor (2015): 6.391

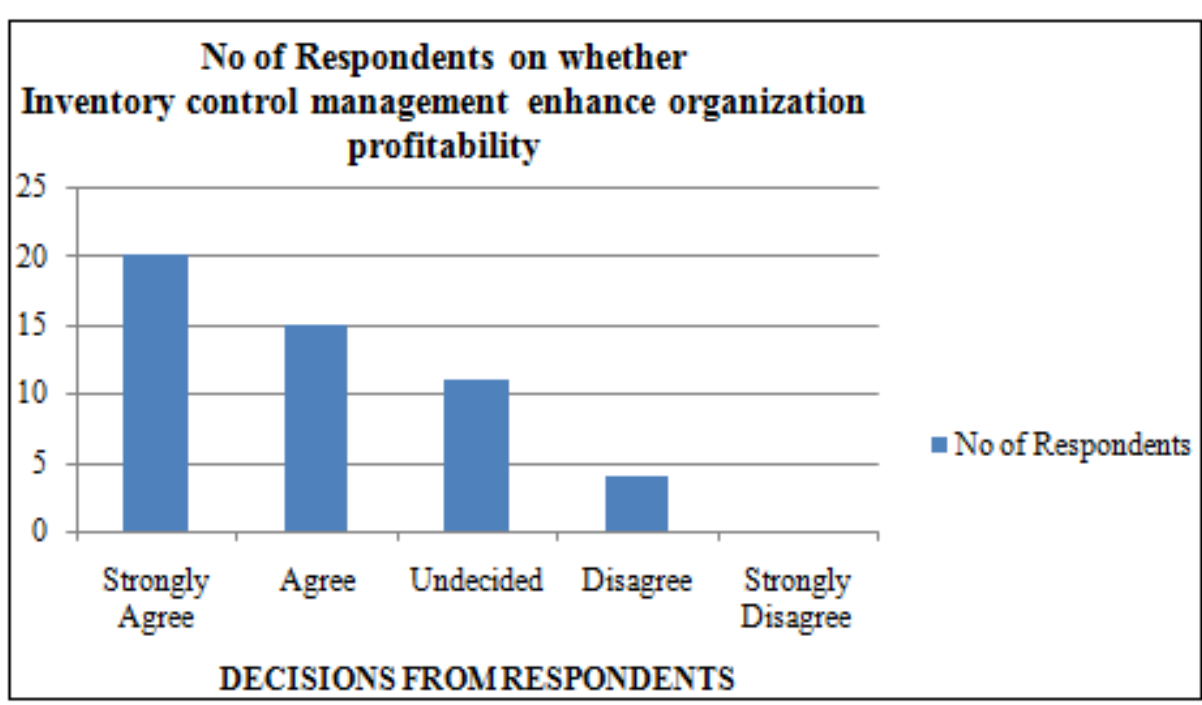

Figure 6: Inventory control management enhance organization profitability

Table 4.7: When inventory control is neglected, cost incurred by the company will be higher

\begin{tabular}{|c|c|c|}
\hline Variables & No of Respondents & $\%$ of Respondents \\
\hline Strongly Agree & 20 & 40 \\
\hline Agree & 23 & 46 \\
\hline Undecided & 7 & 14 \\
\hline Disagree & - & - \\
\hline Strongly Disagree & - & - \\
\hline Total & 50 & 100 \\
\hline
\end{tabular}

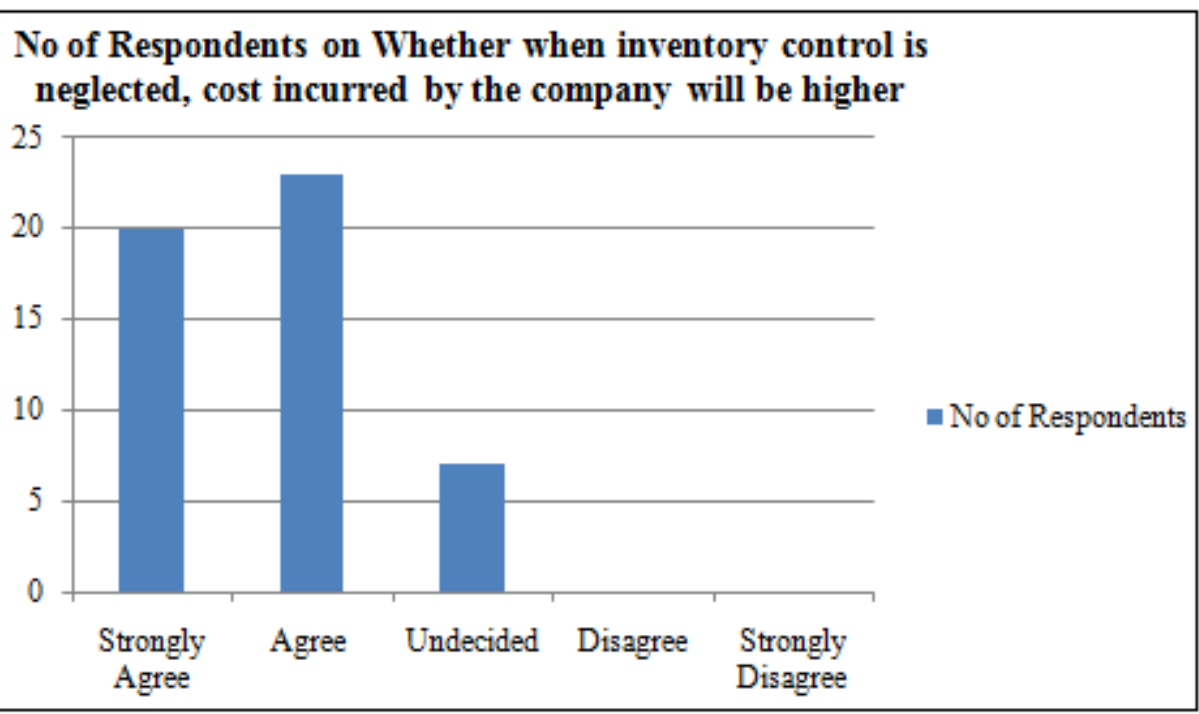

Figure 7: When inventory control is neglected, cost incurred by the company will be higher

Table 4.8: Year spent in the company

\begin{tabular}{|c|c|}
\hline Interval & Frequency \\
\hline $1-5$ & 15 \\
\hline $6-10$ & 10 \\
\hline $11-15$ & 9 \\
\hline $16-20$ & 10 \\
\hline 21 and above & 8 \\
\hline
\end{tabular}

Volume 6 Issue 1, January 2017 www.ijsr.net 


\section{International Journal of Science and Research (IJSR) \\ ISSN (Online): 2319-7064}

Index Copernicus Value (2015): 78.96 | Impact Factor (2015): 6.391

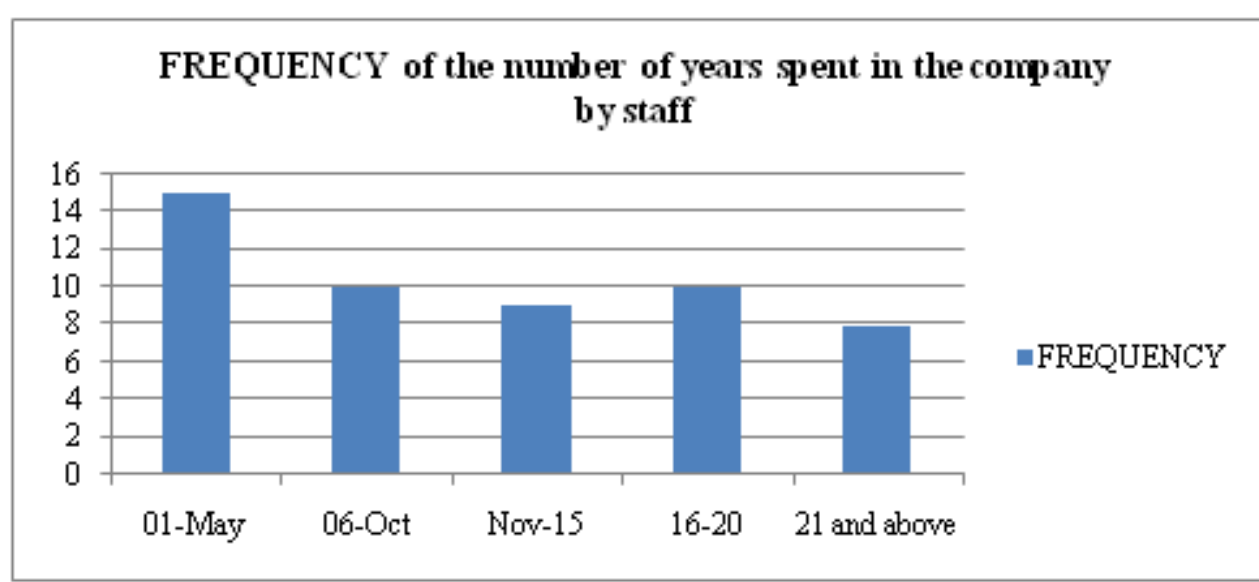

Figure 8: Distribution of respondents based on years spent in the department

Table 4.9: Planned and effective control of inventory improves organization.

\begin{tabular}{|c|c|c|}
\hline Variables & No of Respondents & \% of Respondents \\
\hline Strongly Agree & 22 & 44 \\
\hline Agree & 21 & 42 \\
\hline Undecided & 7 & 14 \\
\hline Disagree & - & - \\
\hline Strongly Disagree & - & - \\
\hline Total & $\mathbf{5 0}$ & $\mathbf{1 0 0}$ \\
\hline
\end{tabular}

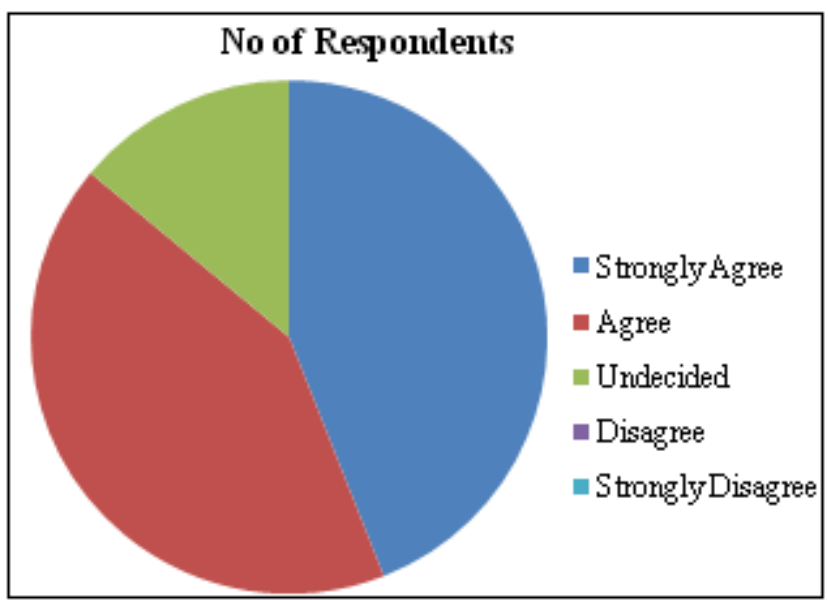

Figure 9: pie chart on whether Planned and effective control of inventory improves organization.

Table 4.10: Proper inventory policy enhances company inventory management

\begin{tabular}{|c|c|c|}
\hline Variables & No of Respondents & \% of Respondents \\
\hline Strongly Agree & 19 & 38 \\
\hline Agree & 23 & 46 \\
\hline Undecided & 5 & 10 \\
\hline Disagree & 2 & 4 \\
\hline Strongly Disagree & 1 & 2 \\
\hline Total & $\mathbf{5 0}$ & $\mathbf{1 0 0}$ \\
\hline
\end{tabular}

Table 4.11: Inventory policy determines the replenishment orders

\begin{tabular}{|c|c|c|}
\hline Variables & No of Respondents & \% of Respondents \\
\hline Strongly Agree & 20 & 40 \\
\hline Agree & 22 & 44 \\
\hline Undecided & 6 & 12 \\
\hline Disagree & 1 & 2 \\
\hline Strongly Disagree & 1 & 2 \\
\hline Total & 50 & 100 \\
\hline
\end{tabular}

Table 4.12: Physical counting inventories eliminates theft and fraud

\begin{tabular}{|c|c|c|}
\hline Variables & No of Respondents & \% of Respondents \\
\hline Strongly Agree & 20 & 40 \\
\hline Agree & 19 & 38 \\
\hline Undecided & 8 & 16 \\
\hline Disagree & 3 & 6 \\
\hline Strongly Disagree & - & - \\
\hline Total & 50 & 100 \\
\hline
\end{tabular}

Table4.13: Company's purchase of raw materials should be after the stock has finished

\begin{tabular}{|c|c|c|}
\hline Variables & No of Respondents & \% of Respondents \\
\hline Strongly Agree & - & - \\
\hline Agree & 5 & 10 \\
\hline Undecided & 10 & 20 \\
\hline Disagree & 18 & 36 \\
\hline Strongly Disagree & 17 & 34 \\
\hline Total & 50 & 100 \\
\hline
\end{tabular}

Table 4.14: Inventory control should be handled by a special department

\begin{tabular}{|c|c|c|}
\hline Variables & No of Respondents & \% of Respondents \\
\hline Strongly Agree & 19 & 38 \\
\hline Agree & 20 & 40 \\
\hline Undecided & 10 & 20 \\
\hline Disagree & 1 & 2 \\
\hline Strongly Disagree & - & - \\
\hline Total & 50 & 100 \\
\hline
\end{tabular}

Table 4.15 The Company should carry out monthly inventory control

\begin{tabular}{|c|c|c|}
\hline Variables & No of Respondents & $\%$ of Respondents \\
\hline Strongly Agree & 6 & 12 \\
\hline Agree & 15 & 30 \\
\hline Undecided & 18 & 36 \\
\hline Disagree & 8 & 16 \\
\hline Strongly Disagree & 3 & 6 \\
\hline Total & $\mathbf{5 0}$ & $\mathbf{1 0 0}$ \\
\hline
\end{tabular}

\section{Test of Hypotheses}

Chi Square test was conducted to test the following hypotheses

\section{Hypothesis 1}

Ho: Irregular inventory control does not affect the profit position of the company. 


\section{International Journal of Science and Research (IJSR) \\ ISSN (Online): 2319-7064 \\ Index Copernicus Value (2015): 78.96 | Impact Factor (2015): 6.391}

$\mathbf{H}_{\mathbf{i}}$ : Irregular inventory control affects the profit position of the company.

\section{Chi-Square Tests}

\begin{tabular}{|c|c|c|c|}
\hline & Value & df & Significance \\
\hline Pearson Chi-Square & 11.286 & 1 & 0.001 \\
\hline
\end{tabular}

\section{Interpretation}

The Chi square results shows a significant effect since $(p<0.05)$. Therefore, we reject Hoand conclude that that irregular inventory control affects the profit of the company.

\section{Hypothesis 2}

Ho: Inventory control does not determine how a business organization refills its stock.

$\mathbf{H}_{\mathbf{i}}$ : Inventory control does determine how a business organization refills its stock.

\begin{tabular}{|c|c|c|c|}
\hline & Value & df & Significance \\
\hline Pearson Chi-Square & 5.120 & 1 & 0.024 \\
\hline
\end{tabular}

\section{Interpretation}

The Chi square results shows that significant effect at $(\mathrm{p}<0.05)$. We reject $\mathrm{H}_{0}$ and conclude that inventory control determines how a business organization refills its stock.

\section{Hypothesis 3}

Ho: Inventory control does not determine the general effect on a business organization.

$\mathbf{H}_{\mathbf{i}}$ : Inventory control does determine the general affect on a business organization.

\begin{tabular}{|c|c|c|c|}
\hline & Value & df & Significance \\
\hline Pearson Chi-Square & 6.411 & 1 & .011 \\
\hline
\end{tabular}

\section{Interpretation}

The Chi Square test was significant at $(\mathrm{p}<0.05)$ since the value of 0.011 is less than 0.05 . This implies that the inventory control system of any organization will eventually affect the running and the success of that organization.

\section{Summary of Results}

From figure 3 , it is observed that the age of staff within the range of 26-35 years recorded the highest number of respondents with $40 \%$ representing 20 respondents. Others have $30 \%$, representing 15 persons, $20 \%$ representing 10 respondents and $10 \%$ representing 5 respondents for the staff withing the range of 15-25years, 36-45years and 45 and above respectively.

Table 4.1 showed that 55\% representing 29 respondents of employees are male and $45 \%$ representing 21 respondents are female. It could be seen from table 4.2 that $42 \%$ representing 22 of the total respondents are single and $58 \%$ representing respondents are married.

Figure5 shows that 52\% representing 26 respondent has B.SC/HND, whereas $16 \%, \quad 32 \%$ representing8, 16 respondents are $\mathrm{OND} / \mathrm{GCE} \mathrm{A} / \mathrm{L} / \mathrm{NCE}$ and WAEC $\mathrm{O} / \mathrm{L} / \mathrm{GCE}$ $\mathrm{O} / \mathrm{L}$ holders respectively.

Figure 8 showed that there are higher numbers of respondents within the range of 1-5years of experience with the percentage of $30 \%$ representing 15 respondents, whereas $20 \%$ representing 10 respondents are within the range of 6 10 , and 16-20 years respectively. Those wthin the range of 11-15 years has $18 \%$ representing 9 respondents. 21-25 years of age has $16 \%$ representing 8 respondents which is the least.

Figure 4 shows that most of the samples are gotten from management with $32 \%$ representing 16 respondents. Thisis followed by supervisors $28 \%$ representing 14 respondents and clerical with $22 \%$ representing 11 respondents.Other units have $18 \%$ representing respondents and the least is from store with $16 \%$ representing 8 respondents.

Row 2 of table 4.6 shows that the respondents that strongly agree that inventory control management will enhance organization profitability is with $40 \%$ representing 20 respondents.30\% representing 15 respondents agreedas shown in row 3 , while $22 \%$ representing 11 respondents where undecisive as shown in row4. 8\% representing 4 respondents disagreed as shown in row 5 , but there was no record for strongly disagree.

Table4.7 revealed that the respondents who agree that when the control of inventories is neglected, the costs incurred by the company will be higher is with $46 \%$ representing 23 respondents, $40 \%$ representing 20 respondents represents strongly agree, $14 \%$ representing 7 respondents were undicisive, and $0 \%$ for strongly disagree.

Table 4.9 shows that $44 \%$ representing 22 respondents strongly agreed that Planned and effective control inventory result in improvement of the organization. Wheras $42 \%$ representing 21 respondents agreed, 14\% representing 7 respondents were indecisive, $0 \%$ representing both disagree and strongly disagree

The percentage of $46 \%$ representing 23 respondents agreed that proper inventory policy enhances the company inventory management; 38\% representing 19 respondents strongly agreed, $10 \%$ representing 5 respondents were indecisive, $4 \%$ representing 2 respondents disagreed and $2 \%$ representing 1 respondent strongly disagreed as shown in table 4.10.

The percentage of $44 \%$ representing 22 respondents agreed that inventory policy determine when and how replenishment orders are to be place; $40 \%$ representing 20 respondents strongly agreed, $12 \%$ representing 6 respondents indecisive, $2 \%$ representing 1 respondent disagreed and $2 \%$ representing 1 respondent strongly disagreed as shown in table 4.11 .

The table 4.12 showed that $40 \%$ representing 20 respondents strongly agreed that physical counting inventories can help reduce or eliminate theft and fraud, 38\% representing 18 respondents agreed, 16\% representing 8 respondents were indecisive, $6 \%$ representing 3 respondents disagreed while $0 \%$ strongly disagreed.

The table 4.13 showed that $34 \%$ representing 17 respondents strongly disagreed, $36 \%$ representing 18 respondents disagreed, $20 \%$ representing 10 respondents were indecisive,

\section{Volume 6 Issue 1, January 2017




\section{International Journal of Science and Research (IJSR) \\ ISSN (Online): 2319-7064 \\ Index Copernicus Value (2015): 78.96 | Impact Factor (2015): 6.391}

$10 \%$ representing 5 respondents agreed and $0 \%$ strongly agreed that company's purchase should be after the stock has finished.

The table 4.14 shows that $38 \%$ representing 19 respondents strongly agreed, $40 \%$ representing 20 respondents agreed, $20 \%$ representing 10 respondents were indecisive, $2 \%$ representing 1 respondent disagreed and $0 \%$ strongly disagreed that inventory control should be handled by a special department

The table 4.15 shows that $12 \%$ representing 6 respondents strongly agreed, $30 \%$ representing 15 respondents agreed, $36 \%$ representing 18 respondents were indecisive, $16 \%$ representing 8 respondents disagreed and $6 \%$ representing 3 respondents strongly disagreed that company should carry out monthly inventory control.

The Chi square results of test one shows that irregular inventory control affects the profitability position of the company at $(p<0.05)$. However, it was observed that regular inventory control improves the profitability of a business organization. In addition, the influence of management on inventory control towards profitability of the company revealed a positive significance $(\mathrm{p}<0.01)$ as shown in test three. Test 2 shows that inventory control determined the general effect on a business organization. This implies that the inventory control system of any organization will eventually affect the running and the success of that organization. This indicates that inventory control determines how a business organization refills its stock since it is only by it, goods that have been exhausted from the store can be identified and replaced.

\section{Conclusions}

Inventory control is an unavoidable measure in smooth running of any organization. It is used to ensure the continuous production of goods. Inventory control, when fully understood, will lead to ccontinuousexistence, performance of an organization in meeting demand of their customers.From our findings, it is a fact that inventory control is very important in every organization in order to achieve the desired goal of maximizing profit.

\section{References}

[1] Asika N. (2002): Research Methodology in The Behavioral Sciences $1^{\text {st }}$ Edition Longman Nigeria Plc, Ikeja, Lagos. Pp 1-3.

[2] Okoth, O. (2012, July 26). Billions of money returned to Treasury by Government Ministries. The Kenya Standard Newspaper. (pp. 1 \& 9).

[3] Osborne, D., \& Plastrik, P. (1997). Banishing Bureaucracy: The Five Strategies for Reinventing Government (NY): Addison-Wesley.

[4] Silver, E. (1981). Operations research in inventory management: A review and critique. Operations Research, 29(4), 628-645.

\section{Appendix 1}

Questionnaires

\section{Section A}

Please supply answers to the questions by ticking the appropriate.

1. Age: 16 - 25 years [ ] $26-35$ years [ ] $36-45$ years [ ] 46 years and above []

2. Gender: Male [ ] Female [ ]

3. Highest Educational Qualifications: WAEC/ OL/GCE/OL [ ] ,OND/GCE/AL/NCE [ ], B.SC/HND/MSC/MBA [ ]

4. Department: Accounting[ ], Production [ ], Storage [ ], Purchasing [ ], Sales [ ],

5. Status: Management [ ], Supervisory [ ], Clerical [ ], Others [ ]

6. Marital Status: Single [ ], Married [ ]

7. Years Spent: 1-5yrs[ ], 6-10yrs[ ], 11-15yrs[ ],16-20yrs[ ],21-25yrs[ ],26yrs upward [ ]

\section{Section B}

This section is based on factors that influence Inventory Control on Profitability of a Business Organization (a case study of DUFIL Prima Foods Limited Choba, Port Harcourt.). Please supply answers to the questions below. Comments can be added. Below is a description of the scale.

5 -Strongly Agree, 4-Agree, 3- Undecided, 2- Disagree, 1Strongly Disagree

\begin{tabular}{|c|c|c|c|c|c|c|c|}
\hline $\mathrm{S} / \mathrm{N}$ & Question & 5 & 4 & 3 & 2 & 1 & Comments \\
\hline 1. & Responses on whether inventory control management will enhance organization profitability & & & & & & \\
\hline 2. & $\begin{array}{l}\text { Responses on whether when the control of inventories is neglected, the cost incurred by the } \\
\text { company will be higher }\end{array}$ & & & & & & \\
\hline 3. & $\begin{array}{l}\text { Responses on whether a well planned and effective controlled inventory can result in } \\
\text { improvement of the organization. }\end{array}$ & & & & & & \\
\hline 4. & Responses on whether irregular inventory control affects profits position of the company & & & & & & \\
\hline 6. & Responses on whether Economic Order Quantity minimizes the balance of cost & & & & & & \\
\hline 7. & Responses based on whether proper inventory policy enhances company inventory management & & & & & & \\
\hline 9. & $\begin{array}{l}\text { Responses based on whether Economic Order Quantity should always be applied to the most } \\
\text { important costly inventory items }\end{array}$ & & & & & & \\
\hline 10. & $\begin{array}{l}\text { Responses based on whether Physical Counting Inventories can help reduce or eliminate theft and } \\
\text { fraud }\end{array}$ & & & & & & \\
\hline 11. & Responses on whether company's purchase of raw materials should be after the stock has finished & & & & & & \\
\hline 13. & Responses on whether inventory control should be handed by a special department & & & & & & \\
\hline 14. & Responses on whether the company should carryout monthly inventory control & & & & & & \\
\hline
\end{tabular}

